\title{
Hvordan leger ikke ønsker å dø
}

I vår del av verden bruker vi store ressurser på kritisk syke. Dermed får mange mulighet til å overleve alvorlige sykdommer og skader. Men det skjer også mye overbehandling, der svært gamle eller svært syke pasienter behandles med full intensivmedisinsk innsats til tross for dårlig prognose. Det fører til at mange av disse menneskene gjennomgår et langvarig intensivopphold forbundet med mye ubehag, lidelse og sorg før de dør.

Som anestesilege tilbringer jeg en stor del av arbeidstiden på intensivavdelingen, der det er et privilegium å være med på å redde liv. Imidlertid er jeg ofte vitne til at dødsprosessen forlenges unødig når alvorlig syke pasienter som er kommet i livets sluttfase, overflyttes til overvåkingsavdeling for å få krevende maskinell pustestøtte før de dør. For disse ville lindrende behandling vært bedre. Det er heller ikke uvanlig at vi får inn gamle og demente som har fått hjertestans på sykehjemmet og er blitt gjenopplivet. Fordi hjertet har begynt å slå igjen, innlegges de i intensivavdelingen. Oftest dør de kort tid etter - $\mathrm{i}$ en seng full av slanger, ledninger og teknisk utstyr. Det er grunn til å spørre om ikke disse pasientene burde sluppet gjenoppliving, da prognosen er svært dårlig (1).

Det virker som om vi - både leger og allmennhet - er blitt redde for å la mennesker dø naturlig. Økte forventninger til hva leger kan og bør hjelpe med, kan resultere i krav om ytelser det ikke alltid er grunnlag for å anbefale (2). I en spørreskjemaundersøkelse blant norske leger svarte rundt halvparten at de gjør unødvendige medisinske intervensjoner for å dekke seg selv, og nesten tre firedeler svarte at de opplever risikoen for å gjøre feil som psykisk belastende. Leger lar seg påvirke av press fra pasienter og deres nærstående (3). Er mye av overbehandlingen et resultat av urealistiske forventninger fra pårørende og av legers angst for kritikk fra pårørende og kolleger? Er det egentlig denne angsten vi behandler? Jeg kjenner kolleger som er blitt truet av pasientenes nærmeste dersom det ikke blir gjort full intensivmedisinsk innsats, til tross for at legen anser det som nytteløst.

Det kan ikke forventes at personer uten medisinsk erfaring skal forstå hvor belastende livsforlengende behandling kan være. De har heller ikke grunnlag for å vurdere prognosen til en pasient. Som leger må vi formidle dette til pasient og pårørende på en tillitvekkende og empatisk måte. Det er grunn til å tro at mye overbehandling kunne vært unngått hvis legene i sykehus og sykehjem tidlig hadde tatt seg tid til å samtale med pasienten om fremtidig behandling og om det skal settes en begrensning, for eksempel når det gjelder gjenoppliving eller respiratorbehandling. Geriatriske pasienter er overveiende positive til slike forhåndssamtaler og har viktige meninger om behandling i livets sluttfase - livskvalitet betyr mer enn livslengde (4).
Leger vet bedre enn andre at moderne medisin har sine begrensninger. Så hvordan ønsker de selv å dø? Det foreligger flere studier, blant annet fra USA, som viser en klar forskjell mellom hvordan legene selv ønsker seg avslutningen på livet og hvordan pasientene deres dør (5). Leger som blir rammet av uhelbredelig kreft, velger ofte mindre behandling enn det ikke-leger gjør. De velger oftere å tilbringe resten av levetiden med familien og gjøre lystbetonte ting for så å dø hjemme - fremfor å gjennomgå krevende behandling som kanskje kunne forlenget livet med noen uker eller måneder, men som ville gitt dårligere livskvalitet (6).

I en amerikansk studie hadde to tredeler av legene som ble spurt, lagt planer for den behandlingen de ønsket i livets sluttfase. Nesten alle avslo å bli gjenopplivet. De fleste ønsket smertelindring, men ikke livsforlengende behandling (7). Andre studier støtter opp om disse resultatene (8). Som lege har man sett så mange tragiske utfall at man forstår at døden ikke alltid er det verste. Det går an å bli «reddet» til et liv ingen ønsker seg, for eksempel med alvorlig hjerneskade etter hjertestans.

Døden innhenter oss alle. Det å unnlate å gjøre seg tanker om hvordan man ønsker å dø - eller snarere hvordan man ikke ønsker å dø - kan føre til en unødig lang og vond dødsprosess. Det kan være for sent å ta stilling til dette spørsmålet når man først er blitt kritisk syk og ute av stand til å formidle sin vilje. Vi ønsker alle å få best mulig behandling hvis vi skulle bli alvorlig syke, men den «beste» behandlingen er ikke alltid den livsforlengende. Ofte er beste behandling lindrende tiltak som kan gjøre de siste dagene av livet verd å leve.

\section{Litteratur}

1. van de Glind EM, van Munster BC, van de Wetering FT et al. Pre-arrest predictors of survival after resuscitation from out-of-hospital cardiac arrest in the elderly a systematic review. BMC Geriatr 2013; 13: 68.

2. Gulbrandsen P, Førde R, Aasland OG. Hvordan har legen det som portvakt? Tidsskr Nor Lægeforen 2002; 122: 1874-9.

3. Legekårsundersøkelsen 1993-1995. Oslo: Den norske legeforening, 1995.

4. Friis P. Førde R. Forhåndssamtaler med geriatriske pasienter. Tidsskr Nor Legeforen 2015; 135: 233-5.

5. Pizzo PA, Walker DM. Should we practice what we profess? Care near the end of life. N Engl J Med 2015; 372: 595-8.

6. Murray K. How doctors die. Zozola Public Square 30.11.2011. www.zocalopublicsquare.org/2011/11/30/how-doctors-die/ideas/nexus (6.4.2015).

7. Gallo JJ, Straton JB, Klag MJ et al. Life-sustaining treatments: what do physicians want and do they express their wishes to others? J Am Geriatr Soc 2003 51: $961-9$.

8. Periyakoil VS, Neri E, Fong A et al. Do unto others: doctors' personal end-of-life resuscitation preferences and their attitudes toward advance directives. PLoS ONE 2014; 9: e98246. 